\title{
Strategic Alignment across a Tourism Business Ecosystem
}

\author{
By Willem Selen* \\ Robert Ogulin ${ }^{\dagger}$
}

\begin{abstract}
The tourism experience in a destination is evaluated by a visitor at a holistic level across a multiplicity of service encounters, facilitated by a web of tourism-related organisations engaged in different activities, often referred to as the tourism supply chain (TSC) or tourism value chain (TVC). Earlier tourism studies have pointed to the need to progress our understanding of the TSC more holistically to include its wider environment, as the destination it is operating in presents a unique composition of contextual factors that define its experiences offered to visitors, making up a business ecosystem. Such a business ecosystem consists of not only intermediaries and industry partners, but also various stakeholders including governments, visitors, and the natural environment. This research focuses on preliminary insights in relation to strategic alignment across a wider business ecosystem; with application to the Sunshine Coast - region in Australia as an example of a Destination Business Ecosystem.
\end{abstract}

Keywords: Business ecosystem, Strategic alignment, Tourism destination, Tourism supply chain, Value ecology.

\section{Introduction}

Companies in tourism businesses increasingly compete between tightly integrated Tourism Supply Networks (TSNs), rather than between separate firms and supply chains (Ketchen et al. 2014). Network partners of such TSNs consist of tourists; companies that act as service providers, or intermediaries; government agencies; regulators; technology providers; communities; and consultants; making up a Tourism Value Ecology or Tourism Business Ecosystem (TBE) (Baggio and Chiappa 2014, Kline et al. 2014). The competition is complemented by an increased cooperation in order to boost agility, flexibility and efficiency, often leading to an environment of coopetition (Sigala 2008, Kylanen and Rusko 2011).

Recently, research has highlighted the relevance of managing a wide range of shared capabilities towards common goals, and collaborating to co-create and co-deliver sustained value for all network partners leading to the need for effective alignment across the TBE (Gereffi et al. 2005, Gligor and Holcomb 2012, Halldorsson et al. 2007, Lemmetyinen and Go 2009, Pechlaner et al. 2014, Romero and Tejada 2011, Stank et al. 2011, Wong et al. 2012).

\footnotetext{
${ }^{*}$ Professor, School of Business - FAB, University of the Sunshine Coast, Australia.

${ }^{\dagger}$ School of Business - FAB, University of the Sunshine Coast, Australia.
} 
Focusing on a tourism destination as the wider tourism business ecosystem, Brawn (2005) notes that "... it is possible for a destination to develop backward economic linkages if there is a critical mass of firms, strategic infrastructure, inclusive networks, leadership, a pool of skills, entrepreneurship, and knowledge flows are in place [then it becomes likely] to create a unique set of core competencies and tourism products".

This paper addresses a number of issues for managers and researchers of tourism destinations. Firstly, organisations within tourism destinations need to find a balance between competing for customers and resources, and cooperating to stimulate visitor demand. We refer to supply chain alignment (SCA) as an established concept (Wong et al. 2012) to describes the importance of aligning strategies, processes (Van Hoek et al. 2008), IT (Qrunfleh and Tarafdar 2014), and people (Ashenbaum et al. 2009) capabilities in TSC towards the customer. It has been shown that SCA (i.e. the integration and collaboration in a supply chain network), can have a positive impact on the delivery of products and services (Green et al. 2012), but also in addressing sustainability goals (Brindley and Oxborrow 2014, Qrunfleh and Tarafdar 2014). We extend the application of that concept to the TSC and analyse the alignment of capabilities, which may lead to better supply chain network performance and value creation. The development of an alignment framework at the wider business ecosystem in a tourism context addresses a gap in the literature, as recently stated by Song et al. (2013), who argue that "research on the preconditions for, and effects of, different governance alignment mechanisms, as well as the evaluation of outcomes, is still limited" (Song et al. 2013: 25).

This paper is organised as follows. First, a theoretical background is provided for the need and relevance of strategic alignment within a wider tourism value ecology or business ecosystem. Next, a business/tourism destination is described as a business ecosystem, followed by a practical example. Finally, preliminary insights regarding strategic supply chain alignment across such a wider business ecosystem are described, as this research is ongoing.

\section{Theoretical Background}

Consumers in tourism are seen as networked, active, informed, and involved in consumer communities, and co-creating their tourism experience; being transformed from "passive audiences" to "active players" (Cabbidu et al. 2013) in consumer-driven value co-creation (Prahalad and Ramaswamy 2004). Moreover, service is provided through a complex combination of organisational resources (Cova and Salle 2008, Vargo and Lusch 2004) and increasingly through supply chains or networks.

A typical Tourism Supply Chain (TSC) involves the suppliers of all tourism goods and services that are delivered to the end consumers-the tourists. Generally speaking, a TSC includes the tourists as end customers (Huang et al. 
2012). TSC as a distribution system not only focuses on the distribution of tourism products to tourists, but also concerns collaboration and competition issues within the enterprises in the system. Tourism can be understood as a practice that involves networked orderings of people, natures, materials, mobilities and cultures; production as well as consumption of those different elements (Van der Duim 2007).

Song et al. (2013: 15) stated that "little work has been done to examine the effects of legal, economic, cultural, and other contextual factors on governance issues. Even less attention has been paid to the effect of the governance environment on the integration of tourism distribution channels and the sustainability of the value chain as a whole". This points to the need to study the tourism destination as a broader business ecosystem or value ecology. Business ecosystems are made up of customers, suppliers, producers, and other stakeholders -even competitors- interacting with one another to produce complementary goods and services in a particular market segment space (Moore 1998). Hearn and Pace (2006) state that a viable paradigm shift under the value ecology system includes a transition from customer to co-creator, from product value to network value, and from simple cooperation and competition to co-opetition. As such, we summarise the main differences between a TSC and TBE in Table 1. Tourism networks therefore are complex and ever changing entities that develop and evolve over time in response to environmental and organisational developments and demands (March and Wilkinson 2009).

Table 1. Tourism Supply Chain vs Tourism Business Ecosystem

\begin{tabular}{|c|c|c|}
\hline Attributes & TSC & TBE \\
\hline Role of & consumer & co-creator \\
\hline $\begin{array}{l}\text { customer } \\
\text { Source of } \\
\text { value }\end{array}$ & product & network \\
\hline Relationships & collaboration & $\begin{array}{l}\text { co-opetition and } \\
\text { collaboration }\end{array}$ \\
\hline Business model & hierarchical & complex \\
\hline $\begin{array}{l}\text { Activities } \\
\text { coordination }\end{array}$ & linear, sequential & $\begin{array}{l}\text { non-linear, } \\
\text { simultaneous }\end{array}$ \\
\hline
\end{tabular}

The above indicates a need to study strategic supply chain alignment (SCA) in a wider tourism destination business ecosystem, where supply chain capabilities are determined by the combination and intensity of sharing strategies, information, process knowledge, skills, and incentives across the supply chain (Ogulin 2014). SCA is based on the Resource-Based-Theory of the firm (Barney et al. 2001, Grant 1991, Wernerfelt 1995) and explains how different resources and capabilities within (Van Hoek et al. 2008) and across, businesses are aligned with customers and markets (Jüttner et al. 2006) in order 
to achieve performance improvements for one company and/or the entire network. SCA in tourism can therefore be described as the efficient and effective allocation of tourism supply chain resources and related capabilities to better serve customers and markets, improve the coordination of product, process and information flows, and to create value for shareholders and stakeholders (Ogulin 2014). Such alignment is called for in a tourism destination as a TBE, where with the increasingly important role of the tourism customer as a co-creator of products and services, a range of destination and tourism services are being combined very flexibly. Next, we elaborate on a (tourism) destination as a business ecosystem.

\section{(Tourism) Destination Business Ecosystem}

A business ecosystem is a network which comprises buyers, suppliers and producers of products or services, as well as the socio-economic environment, and institutional and regulatory frameworks (Moore 1998). It may be complemented by a technological infrastructure aimed at creating a digital business ecosystem environment that supports cooperation, knowledge sharing, and development of open and adaptive technologies and evolutionary business models (Stanley and Briscoe 2010).

In this vein, a tourism destination may be considered a network of interrelated stakeholders (both public and private). The performance of a tourism destination as a whole depends on the web of connections between the various players, and not only on the intrinsic characteristics of the destination (March and Wilkinson 2009). Contributions to destination governance often advocate a form of self-governance that depends on the cooperation between all relevant stakeholders, and aims to develop joint strategies and collective action (D'Angella and Go 2009, Jamal and Getz 1995, Palmer and Bejou 1995, Zehrer et al. 2014). In principle, however, one cannot assume that a-priori a destinations' actors are willing to work together. Transaction costs (Williamson 1979) and the existence -or non-existence- of social ties need to be taken into consideration (Presenza and Cipollina 2010, Zehrer et al. 2014). Therefore, actors are needed who are able to identify and articulate collective interests, establish links, as well as coordinate negotiations. This crucial task of enhancing stakeholder collaboration is normally assigned to Destination Marketing Organisations (DMOs). Consequently, networking capability is considered a primary prerequisite for evaluating DMO's performance in a positive manner (D'Angella and Go 2009, Halme 2001, Volgger and Pechlaner 2014).

Focal organisations can improve the overall performance of a business ecosystem by providing a stable and predictable set of common assets. Focal organisations may increase ecosystem productivity by simplifying the complex coordination of network participants with one another, or by enabling processes that make the creation of new products by third parties more efficient. They can enhance ecosystem robustness by consistently incorporating 
technological innovations and by providing a reliable point of reference. And they can encourage ecosystem niches by offering innovative technologies to a variety of third-party organisations (Davenport et al. 2007).

Finally, rather than drawing precise boundaries of an ecosystem, one should try to systematically identify the organisations in the business ecosystem with which one's future is most closely intertwined, and determine the dependencies that are most critical to one's business. Such dependencies may run into many other businesses, and it is therefore helpful to subdivide a complex ecosystem into a number of related groups of organisations, or business domains. For an ecosystem to function effectively, each domain in it that is critical to the delivery of a product or service should be "healthy"; weakness in any domain can undermine the performance of the whole (Iansiti and Levien 2004). Next, we turn to a discussion of strategic alignment across a business ecosystem.

\section{Strategic Alignment across a Business Ecosystem}

Strategic Alignment relates to inter-organisational linkages that are directed to a course of action to achieve an intended set of goals. Strategic alignment in a network may help maximizing return on the investment, achieving competitive advantage, and providing direction and flexibility to react to challenges and opportunities (Basile and Faraci 2015, Wong et al. 2012, Wu et al. 2014, Yu et al. 2012). For example, within a tourism business ecosystem, the alignment may manifest by maximising the returns from a tourism infrastructure and related land use; from positioning destinations successfully in global markets; or from flexible corporate, business and functional activities of tourism organisations.

The nature and number of stakeholders included in strategy processes varies depending on whether a political economy view or a functionalist view of tourism development is adopted (Sautter and Leisen 1999). While the former view suggests that planning bodies will generally make decisions about stakeholder engagement based on self-interest (instrumental stakeholder theory), the latter holds that all interested stakeholders should contribute to strategies (normative theory) (Stokes 2008).

In terms of governance structure, a destination business ecosystem can either be market-led (tourist demand focused) (Weaver 2014), or product-led (destination resource based) (Stokes 2008). Furthermore, in terms of dominance of stakeholders within the business ecosystem, one can distinguish a community-driven approach, where no particular stakeholder is dominant; or a corporate approach where the network of partners is dominated by either a powerful business or a corporatized government agency. A market-led mind set, in which sustaining visitor numbers or market growth dominates, is in line with a corporate stakeholder style. On the other hand, a product-led perspective, which focuses on sustaining the destination on economic, social, 
cultural and environmental values, may be more closely aligned with a community-driven approach.

Next, we provide a practical example of how the Sunshine Coast-region in Australia profiles itself as a business ecosystem in the development and implementation of its 20-year regional strategic plan; highlighting actors, suggested networked relationships, envisioned capabilities, and re-positioning of the region.

\section{Sunshine Coast Destination}

\section{Sunshine Coast Business Ecosystem}

The Greater Sunshine Coast is a tourism destination, located $115 \mathrm{~km}$ north of Brisbane. With its natural features it is one of the top preferred tourist destinations in Queensland. In 2012/13, total tourism and hospitality sales were $\$ 2.78$ billion, or $11 \%$ of total value for the region and $13.5 \%$ of full time employment, as stated by the Australian Bureau of Statistics (Wardner, 2014).

Recently, the Sunshine Coast (SSC) as a region established a 20-year Regional Economic Development Strategy for 2013-2033 that manifests itself on a business ecosystem-level; comprising development and collaboration across regional business, industry, and council; informed through contributions by SSC residents and community organisations. It is driven by a strategic vision for development of a "New Economy" for the region, expanding and refocusing existing industries such as tourism and leisure to include seven highly relevant sectors with a possibility to contribute significant value to the destination. The seven sectors are health; education and research; tourism, sport and leisure; knowledge industries and professional services; agribusiness; aviation and aerospace; and clean technologies (Sunshine Coast-The Natural Advantage 2013). The stakeholders identified related the pathways below (Sunshine Coast-The Natural Advantage 2013):

\section{Leadership, Collaboration and Identity}

- Identify regional leaders to champion the direction towards the New Economy.

- Highlight that collaboration and partnerships between regional business and industry groups, and government is critical. This includes ensuring the region's planning frameworks and regulatory regimes are aligned with the strategy's goals and priorities.

- Develop a new competitive and dynamic economic identity that will overcome perceptions of the Sunshine Coast being solely a lifestyle or tourism destination. It is stated that such new regional identity needs to be aligned with the vision for the New Economy. 
- Introduce governance structures, including the establishment of a regional economic leadership board to guide the transitions to, and build the identity of, the New Economy.

\section{Capital Investment}

- Secure investment in tourism, digital, transport and community infrastructure through new funding models.

- Develop relevant infrastructure through "game changer" projects that have transformational effects on business, employment and investment growth - and the economy overall.

\section{High-Value Industries}

- Develop seven high value industries focussing on addressing impediments to growth, workforce requirements, supply chains, market opportunities and the identification of key investment targets.

- Create an investment-friendly regulatory environment and recognise that there is a defined Enterprise Corridor (EC) where high-value industries will be established, expand, and mature.

- Enhance connectivity between urban centres in the EC.

- Invest in niche tourism and leisure experiences outside the EC.

- Promote innovation, research, and digital participation.

\section{Local-to-Global Connections}

- Create a regional network and inventory of existing international expertise and relationships to help drive stronger commercial linkages outside the region and leverage new business models, including new public and private investment.

- Establish an annual program of business excursions and export missions, led by Council. Promote the capabilities, products and services of the region's export-ready businesses and suppliers to key foreign markets.

- Ensure Queensland Government Trade Commissioners have access to up-to-date information on the strengths, opportunities and competitiveness of the Sunshine Coast.

- Utilise government grants, and link with government agencies that can reach into target markets, to assist Sunshine Coast businesses to enter new markets nationally and globally.

\section{Investment in Talent and Skills}

- Nurture and develop entrepreneurial talent through the Innovation Centre Sunshine Coast and enable skills and mentoring programs. 
- Promote options to attract skilled migrants through federal and state government programs to attract specialist skills and business expertise.

- Encourage government, industry and business to work collaboratively on innovative measures to retain skills and talent within the region.

- Recalibrate aspects of the education and training sector's offerings to ensure they are clearly targeted to address critical gaps in the region's workforce profile.

With the above articulated plans and actions, an initial 5-year implementation plan was developed that encapsulates strategic visions, actions planned, performance measures, timeframes, lead responsibility (focal organisation), and partners across the region (business ecosystem). This is illustrated in Table 2 for strategic priority B: Development of a recognised, competitive, regional identity for the Sunshine Coast region.

Table 2. Implementation Plan - Priority $B$

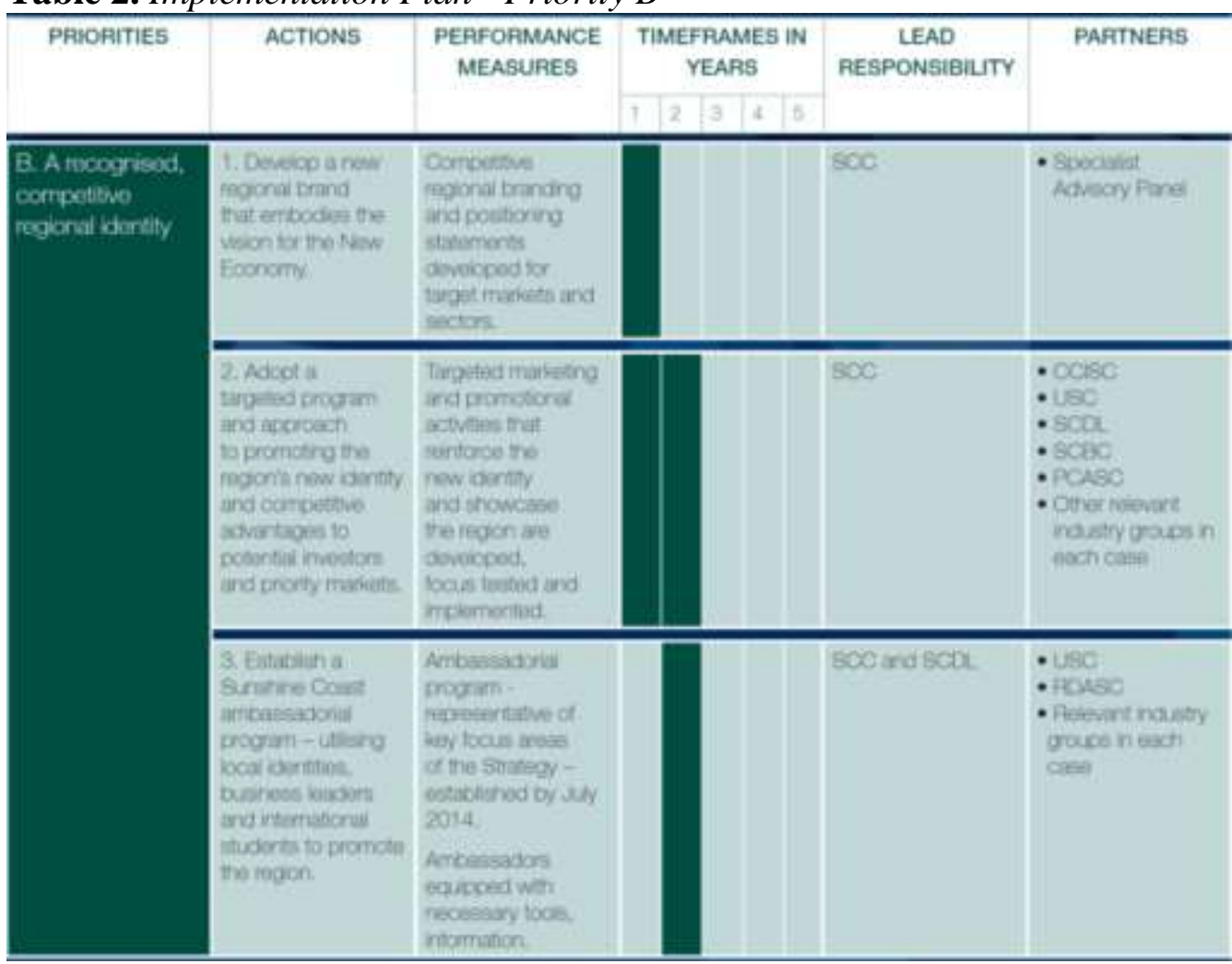

Source: Sunshine Coast-The Natural Advantage 2013.

\section{Strategic Alignment across the Sunshine Coast Region}

The example of the SSC illustrated earlier displays a product-led perspective, with a community-driven approach to strategy making and functionalist view to stakeholder engagement. Yet, one also notices that the 
Sunshine Coast Council seems to take a firm lead (focal organisation role) on many of the activities to be coordinated across numerous stakeholders, including the positioning of the business ecosystem to the market. This raises an issue of whether the proposed approach to include relevant stakeholders as part of the strategy making may be better served through a true communitydriven approach, where such dominant structure is absent. This could include the use of crowd-sourcing technologies to capture input from all stakeholders, as well as emerging smaller innovators in the ecosystem. Furthermore, the ecological literature highlights that it is important for business ecosystems to exhibit variety, and that they are able to absorb external shocks, and foster productive innovation (Iansiti and Levien 2004). This is best facilitated in a business ecosystem that aims beyond sustaining visitor numbers or market growth, and instead extends the focus to include sustaining the destination on economic, social, cultural and environmental criteria. As such, strategic alignment in a destination business ecosystem manifests itself in a destination resource-based environment, without any dominant stakeholders, and a functionalist view of stakeholder engagement that states that all stakeholders should strive to achieve such joint strategic objectives.

It is envisioned that effective strategic alignment across partners of the business ecosystem may improve coordination, communication and strategy setting across national/state/regional levels, particularly in the development stage. Furthermore, it may make funding across the business ecosystem more identifiable, accessible and/or equitable; and facilitate a coordinated economic approach to development and allocation of the use of facilities across public/private sector partnerships. Finally, a key stakeholder database would need to be developed to build networks, clarify roles, and encourage coordinated activities. The above highlights the preliminary stages and insights of strategic alignment across a business ecosystem, which will be further empirically investigated in future research, which is ongoing.

\section{References}

Ashenbaum B, Maltz A, Ellram L, Barratt MA (2009) Organizational alignment and supply chain governance structure: Introduction and construct validation. International Journal of Logistics Management 20(2): 169-186.

Baggio R, Chiappa G (2014) Real and virtual relationships in tourism digital ecosystems. Information Technology and Tourism 14(1): 3-19.

Barney J, Wright M, Ketchen Jr. DJ (2001) The resource-based view of the firm: ten years after 1991. Journal of Management 27: 625-642.

Basile A, Faraci A (2015) Aligning management model and business model in the management innovation perspective: The role of managerial dynamic capabilities in the organizational change. Journal of Organizational Change Management 28(1): 43-58.

Brawn P (2005) The importance of value chains, networks and cooperation as drivers for SMEs' growth, performance and competitiveness in the tourism-related industries. Conference on Global Tourism Growth: A Challenge for SMEs, Proceedings of the International Conference, Gwangju, Korea, pp. 2-11. 
Brindley C, Oxborrow L (2014) Aligning the sustainable supply chain to green marketing needs: A case study. Industrial Marketing Management 43(1): 45-55.

Cabiddu F, Lui T-W, Piccoli G (2013) Managing value in the tourism industry. Annals of Tourism Research 42: 86-107.

Cova B, Salle R (2008) Marketing solutions in accordance with the S-D logic: Cocreating value with customer network actors. Industrial Marketing Management 37: 270-277.

D'Angella F, Go FM (2009) Tale of two cities' collaborative tourism marketing: towards a theory of destination stakeholder assessment. Tourism Management 30: 429-440.

Davenport TH, Leibold M, Voelpel SC (2007) Strategic Management in the Innovation Economy: Strategic Approaches and Tools for Dynamic Innovation Capabilities. John Wiley and Sons.

Gereffi G, Humphrey J, Sturgeon T (2005) The governance of global value chains. Review of International Political Economy 12(1): 78-105.

Gligor DM, Holcomb MC (2012) Understanding the role of logistics capabilities in achieving supply chain agility: a systematic literature review. Supply Chain Management: An International Journal 17(4): 438-453.

Grant, RM (1991) The resource-based theory of competitive advantage: implications for strategy formulation. California Management Review 33: 114-135.

Green KW, Whitten D, Inman RA (2012) Aligning marketing strategies throughout the supply chain to enhance performance. Industrial Marketing Management 41: 1008-1018.

Halldorsson A, Kotzab H, Mikkola JH, Tage S-L (2007) Complementary theories to supply chain management. Supply Chain Management 12(4): 284-296.

Halme M (2001) Learning for sustainable development in tourism networks. Business Strategy and the Environment 10: 100-114.

Hearn G, Pace C (2006) Value-creating ecologies: understanding next generation business systems. Foresight 8(1): 55-65.

Huang Y, Song HY, Huang GQ, Lou JM (2012) A comparative study of tourism supply chains with quantity competition. Journal of Travel Research 51(6): 717729.

Iansiti M, Levien M (2004) Strategy as ecology. Harvard Business Review 82(3): 6878.

Jamal T, Getz D (1995) Collaboration Theory and Community Tourism Planning. Annals of Tourism Research 2(1): 186-204.

Jüttner U, Godsell J, Christopher MG (2006) Demand chain alignment competencedelivering value through product life cycle management. Industrial Marketing Management 35: 989-1001.

Ketchen DJ, Crook TR, Craighead CW (2014) From supply chains to supply ecosystems: implications for strategic sourcing research and practice. Journal of Business Logistics 35(3): 165-171.

Kline C, Hao H, Alderman D, Kleckley JW, Gray S (2014) A spatial analysis of tourism, entrepreneurship and the entrepreneurial ecosystem in North Carolina, USA. Tourism Planning and Development 11(3): 305-316.

Kylanen M, Rusko R (2011) Unintentional coopetition in the service industries: the case of Pyha-Luosto tourism destination in the Finnish Lapland. European Management Journal 29: 193-205

Lemmetyinen A, Go FM (2009) The key capabilities required for managing tourism business networks. Tourism Management 30(1): 31-40. 
March R, Wilkinson I (2009) Conceptual tools for evaluating tourism partnerships. Tourism Management 30: 455-462.

Moore JF (1998) The rise of a new corporate form. Washington Quarterly 21(1): 167.

Ogulin R (2014) Supply chain alignment: a thematic bibliography. Journal of New Business Ideas \& Trends 11(1): 63-75.

Palmer A, Bejou D (1995) Tourism destination marketing alliances. Annals of Tourism Research 22(3): 616-629.

Pechlaner H, Bachinger M, Volgger M, Anzengruber-Fischer E (2014) Cooperative core competencies in tourism: combining resource-based and relational approaches in destination governance. European Journal of Tourism Research $8(5)$.

Prahalad CK, Ramaswamy V (2004) Co-creation experiences: the next practice in value creation. Journal of Interactive Marketing 18: 5-14.

Presenza A, Cipollina M (2010) Analysing tourism stakeholder networks. Tourism Review 65(4): 17-30.

Qrunfleh S, Tarafdar M (2014) Supply chain information systems strategy: impacts on supply chain performance and firm performance. International Journal of Production Economics 147(Part B): 340-350.

Romero I, Tejada P (2011) A multi-level approach to the study of production chains in the tourism sector. Tourism Management 32: 297-306.

Sautter ET, Leisen B (1999) Managing stakeholders a Tourism Planning Model. Annals of Tourism Research 26: 312-328.

Sigala M (2008) A supply chain management approach for investigating the role of tour operators on sustainable tourism: the case of TUI. Journal of Cleaner Production 16(15): 1589-1599.

Song H, Liu J, Chen G (2013) Tourism value chain governance: review and prospects. Journal of Travel Research 52(1): 15-28.

Stank TP, Dittmann JP, Autry CW (2011) The new supply chain agenda: a synopsis and directions for future research. International Journal of Physical Distribution and Logistics Management 41(10): 940-955.

Stanley J, Briscoe G (2010) The ABC of digital business ecosystems. Tourism Review 65(4): 17-30.

Stokes R (2008) Tourism strategy making: insights to the events tourism domain. Tourism Management 29(2): 252-262.

Sunshine Coast - The Natural Advantage - Regional Economic Development Strategy 2013-2033 (2013). Retrieved from http://goo.gl/LXzBvf. [Accessed: 10 May 2015]

Van der Duim R (2007) Tourismscapes an actor-network perspective. Annals of Tourism Research 34: 961-976.

Van Hoek R, Ellinger AE, Johnson M (2008) Great divides: internal alignment between logistics and peer functions. International Journal of Logistics Management 19(2): 110-129.

Vargo SL, Lusch RF (2004) Evolving to a new dominant logic for marketing. Journal of Marketing 68(1): 1-17.

Volgger M, Pechlaner H (2014) Requirements for destination management organizations in destination governance: understanding DMO success. Tourism Management 41: 64-75.

Wardner P (2014) A commentary on the Greater Sunshine Coast economy. Research gate. Retrieved from http://goo.gl/aU84FQ. [Accessed: 10 May 2015]

Weaver DB (2014) Asymmetrical dialectics of sustainable tourism: toward enlightened mass tourism. Journal of Travel Research 53: 131. 
Vol. 2, No. $3 \quad$ Selen et al.: Strategic Alignment across a Tourism Business Ecosystem

Wernerfelt B (1995) The resource-based view of the firm: ten years after. Strategic Management Journal 16(3): 171-175.

Williamson OE (1979) Transaction-cost economics: the governance of contractual relations. Journal of Law and Economics 22(2): 233-61.

Wong C, Skipworth H, Godsell J, Achimugu N (2012) Towards a theory of supply chain alignment enablers: a systematic literature review. Supply Chain Management 17: 419-437.

Wu T, Jim Wu Y-C, Chen YJ, Goh M (2014) Aligning supply chain strategy with corporate environmental strategy: a contingency approach. International Journal of Production Economics 147(Part B): 220-229.

Yu K, Cadeaux J, Song H (2012) Alternative forms of fit in distribution flexibility strategies. International Journal of Operations \& Production Management 32(10): 1199-1227.

Zehrer A, Raich F, Siller H, Tschiderer F (2014) Leadership networks in destinations. Tourism Review 69(1): 59. 